\title{
Aqueous Ultrasound-Assisted Extraction for the Determination of Fluoroquinolones in Mangrove Sediment by High-Performance Liquid Chromatography and Fluorescence Detector
}

\author{
Mônica A. Neves, ${ }^{*, a}$ Gilmar S. Silva, ${ }^{b}$ Natilene M. Brito, ${ }^{b}$ Karla C. M. Araújo, ${ }^{b}$ \\ Edmar P. Marques ${ }^{a}$ and Lanna K. Silva ${ }^{b}$ \\ ${ }^{a}$ Laboratório de Pesquisa em Química Analítica (LPQA), Departamento de Química, \\ Universidade Federal do Maranhão (UFMA), Av. Portugueses, s/n, Bacanga, \\ 65080-040 São Luis-MA, Brazil \\ ${ }^{b}$ Departamento de Química, Instituto Federal de Educação, Ciência e Tecnologia do Maranhão, \\ Monte Castelo Campus, Av. Getúlio Vargas, No. 04, 65030-005 São Luís-MA, Brazil
}

\begin{abstract}
A method for simultaneous analysis of ciprofloxacin (CIP), levofloxacin (LEV) and norfloxacin (NOR) in mangrove sediment was developed using aqueous ultrasound-assisted extraction (UAE), solid phase extraction (SPE) and high-performance liquid chromatography with fluorescence detection (HPLC-FD). The method showed excellent linear correlation coefficient for the three fluoroquinolones $\left(\mathrm{r}^{2}>0.999\right)$ using external calibration curve and good recovery in real sediment samples ranging from 73.73 to $88.85 \%$. The precision showed a relative standard deviation lower than $20 \%$ and detection limits of $1.10,3.33$ and $0.26 \mu^{2} \mathrm{~kg}^{-1}$ to CIP, LEV and NOR, respectively. There was no presence of interfering. After validation, the method was applied in the determination of pharmaceuticals in mangrove sediment in the Paciência River, Maranhão Island, Brazil. Only the CIP antibiotic was found in three of six samples analyzed, with values ranging $56.55-70.45 \mu \mathrm{g} \mathrm{kg}^{-1}$.
\end{abstract}

Keyword: fluoroquinolones, sediment, ultrasound assisted extraction, solid phase extraction

\section{Introduction}

Antibiotics are substances used worldwide in human and veterinary medicine to inhibit the growth of microorganisms, treat diseases (therapeutic purposes), prevent diseases caused by the presence of pathogenic organisms in the human or animal (prophylactic) and to promote growth. ${ }^{1,2}$

The fluoroquinolones antibiotics negatively affect the environment by chronic effect in biota or potential resistance in microorganisms..$^{3-6}$ They are released continuously into the environment as a result of industrial processes, and discharges of commercial products or human or livestock sewage directly into water bodies, soil and sediments. ${ }^{6-8}$

Estimates of worldwide total antibiotic consumption in livestock alone range from 60,000 to 240,000 tons annually. ${ }^{9}$ Until 2030 in some countries, including Brazil, the consumption might increase by $67 \%$. That Brazil is

*e-mail: monicaneves03@gmail.com one of the leaders in poultry and cattle production and exportation implies that a great quantity of antibiotics is used annually in this economic activity. In addition, Brazil has only $40 \%$ of its sewage treated, and in the Northwest region this value drops to $28.8 \%$. These situations imply that much of the antibiotic residue consumed by humans is released into water bodies. ${ }^{10}$

Over the past few years, environmental regulatory agencies in developed countries have worked to establish regulatory guidelines to control harmful substances in the environment, and more specifically, to human health. ${ }^{8-10}$ The main concern is that many emerging contaminants are not yet included in environmental legislation around the world. Currently, only a few isolated compounds have been regulated, although the vast majority still remain without legal definitions as their presence in different matrices. ${ }^{11} \mathrm{At}$ the same time, some studies address the problem focusing on both the presence of these contaminants and the acute and chronic effects on living organisms..$^{11,12}$

Structurally, fluoroquinolones are derived from quinolone. Quinolone is a bicycle structure with nitrogen, 
carboxylic and carbonyl functional groups in positions 1 , 3 and 4 , respectively. ${ }^{13}$ The addition of fluorine in position 7 produces the fluoroquinolones antibiotics. In Table 1 are described the physicochemical properties and chemical structure of some fluoroquinolones: ciprofloxacin (CIP), levofloxacin (LEV) and norfloxacin (NOR). ${ }^{13,17}$ CIP, LEV and NOR have been used in human medicine. CIP and NOR are also used in veterinary applications. ${ }^{20,21}$ The carboxylic and fluorine groups contribute to polar characteristics of fluoroquinolones, resulting in $\log \mathrm{K}_{\mathrm{ow}}$ ranging from -1.03 to $0.89 .{ }^{19}$ Hydroxyl, amide or ketone radicals in fluoroquinolones are able to form complex with cations $\left(\mathrm{Ca}^{2+}, \mathrm{Mg}^{2+}\right.$, and $\left.\mathrm{Al}^{3+}\right)$ commonly found in the environment. ${ }^{13,19}$ The fluoroquinolones have amphoteric properties due to carbonyl and nitrogen functional groups in its structure. The ionizable functional groups carboxylic $\left(\mathrm{pK}_{\mathrm{a} 1}\right)$ and nitrogen $\left(\mathrm{pK}_{\mathrm{a} 2}\right)$ are responsible for cationic, anionic, neutral and zwitterionic species according to $\mathrm{pH}$. The species define fluoroquinolone mobility in solid matrices. ${ }^{10}$

There are few methods described in literature for analysis of the fluoroquinolones in solid environmental matrices, such as soil and sediment of water bodies. ${ }^{22,23}$ Most methods are described for aqueous environmental matrices, for example, high performance liquid chromatography (HPLC) using different detectors, such as UV-Vis, fluorescence and mass spectrometry. ${ }^{22-25}$
The great challenge for analysis of fluoroquinolones in solid matrices involves the presence of organic matter and metallic cations, responsible for the strong interactions with sediment and soil. ${ }^{26}$ The analytical protocol involved in fluoroquinolones analysis in solid samples, such as sediment/soil, is related to sample preparation which requires time-consumption and several steps. In addition, after fluoroquinolones extraction, a subsequent purification protocol is required. The association of these two previous protocol is a precondition for different analytical methods. ${ }^{13}$

For the preparation of solid samples, there are traditional extraction techniques such as mechanical agitation and extraction by Soxhlet. ${ }^{11}$ Alternatives techniques have been studied to improve the performance of extraction of analytes, such as pressurized liquid extraction (PLE), ${ }^{27,28}$ also known as accelerated solvent extraction (ASE), ${ }^{29,30}$ microwave assisted extraction (MAE) $)^{31,32}$ and ultrasound assisted extraction (UAE) ${ }^{33-35}$ Solid phase extraction (SPE) technique has been chosen for purification of extracts due to its efficiency and availability of phases. As an alternative, two SPE cartridges are set up in tandem for purification of the aqueous extracts. ${ }^{25,36}$

The objective of this study was to develop and apply methodology using ultrasound assisted extraction (UAE), solid phase extraction (SPE) and high-performance liquid chromatography with fluorescence detection (HPLC-FD) for simultaneous analysis of CIP, LEV and NOR in

Table 1. Physicochemical properties of fluoroquinoles

\begin{tabular}{|c|c|c|c|c|c|c|c|}
\hline Compound & Structure & $\mathrm{pK}_{\mathrm{a}}$ & $\log \mathrm{K}_{\mathrm{ow}}^{\mathrm{a}, \mathrm{b}}$ & $\begin{array}{c}\mathrm{K}_{\mathrm{d}}^{\mathrm{a}} \text { (soil) / } \\
\left(\mathrm{L} \mathrm{kg}^{-1}\right)\end{array}$ & $\begin{array}{c}\mathrm{K}_{\mathrm{d}}^{\mathrm{a}} \text { (sediment) / } \\
\left(\mathrm{L} \mathrm{kg}^{-1}\right)\end{array}$ & $\begin{array}{l}\text { Zwitterionic } \\
\text { point }(\mathrm{pH})\end{array}$ & Reference \\
\hline CIP & & $\begin{array}{l}\mathrm{pK}_{\mathrm{a} 1}=5.90 \\
\mathrm{pK}_{\mathrm{a} 2}=8.89\end{array}$ & $\begin{array}{c}-2.82 ; \\
2.30 /-0.81\end{array}$ & $\begin{array}{c}74 ; \\
1,277,874 / 21,099\end{array}$ & $\begin{array}{c}794 ; \\
18,620 / 7,000\end{array}$ & 7.5 & $14-16$ \\
\hline LEV & & $\begin{array}{l}\mathrm{pK}_{\mathrm{a} 1}=5.59 \\
\mathrm{pK}_{\mathrm{a} 2}=7.94\end{array}$ & $\begin{array}{c}-2.00 \\
1.30 /-0.72\end{array}$ & - & - & 6.77 & $16-18$ \\
\hline NOR & & $\begin{array}{l}\mathrm{pK}_{\mathrm{a} 1}=6.20 \\
\mathrm{pK}_{\mathrm{a} 2}=8.55\end{array}$ & $\begin{array}{c}-3.78 \\
1.45 /-1.17\end{array}$ & $\begin{array}{c}41 ; \\
335,633 / 29,876\end{array}$ & $30 ; 75 / 54$ & 7.34 & $14,16,19$ \\
\hline
\end{tabular}

$\mathrm{K}_{\mathrm{ow}}$ : octanol-water partition coefficient; $\mathrm{K}_{\mathrm{d}}$ : distribution coefficient. ${ }^{\mathrm{a}} \log \mathrm{K}_{\mathrm{ow}}$ and $\mathrm{K}_{\mathrm{d}}$ were presented as minimum and maximum/mean; ${ }^{\mathrm{b}} \mathrm{depending}$ on reference denoted as $\mathrm{K}_{\text {ow }}, \mathrm{P}_{\text {ow }}, \mathrm{P}_{\text {app }}$, or D. 
mangrove sediments in the estuary of the Paciência River, located in Maranhão Island, belonging to legal Amazon, Brazil.

\section{Experimental}

\section{Standards and reagents}

CIP, LEV and NOR were obtained from Sigma-Aldrich (St. Louis, MO, USA) both with a minimum purity of $98 \%$. All organic solvents used have chromatographic grade (methanol, acetonitrile and dichloromethane) and were obtained from Merck (Darmstadt, Germany). Other reagents used have analytical purity (hexahydrate of magnesium nitrate, ammonium hydroxide, phosphoric ortho acid, formic acid, monobasic sodium phosphate, monobasic potassium phosphate, disodium EDTA, citric acid, sodium citrate) and were obtained from Isofar (Rio de Janeiro, Brazil). The ultrapure water used was obtained from Milli-Q Merck Millipore systems (Darmstadt, Germany). All glassware used was previously washed with Extran $®$ alkaline solution 5\% and rinsed with ultraclean water.

\section{Instrumentation}

The chromatographic system used was liquid chromatography Shimadzu LC 20AT Prominence, model DGU-20A with two high-pressure pumps coupled to a fluorescence detector RF-10AXL, also from Shimadzu, and an injector with $20 \mu \mathrm{L}$ of the capacity. For control of equipment and data collection, it was used a microcomputer and LCsolution ${ }^{\circledR}$ software (version 1.11 SP1, Shimadzu).

Separation by liquid chromatography was performed using C18 Luna column, Phenomenex $(250 \times 4.6 \mathrm{~mm}$, $5 \mu \mathrm{m}$ particles), mobile phase $\mathrm{MeOH} /$ phosphate buffer ( $\mathrm{NaHPO}_{4} \cdot \mathrm{H}_{2} \mathrm{O}$ to $0.04 \mathrm{~mL} \mathrm{~min}{ }^{-1}$, pH 3 with $\mathrm{H}_{3} \mathrm{PO}_{4} 85 \%$ ) ratio $30: 70(\mathrm{v} / \mathrm{v})$, isocratic elution, flow rate $1 \mathrm{~mL} \mathrm{~min}^{-1}$ and detection by fluorescence at wavelengths of 280 and $450 \mathrm{~nm}$ for emission and excitation, respectively.

\section{Study area and sample preparation}

The Paciência River has $32 \mathrm{~km}$ of extension, with estuarine characteristics. On its drainage basin, $171.74 \mathrm{~km}^{2}$, there are four cities: São Luís, Paço do Lumiar, Raposa and São José de Ribamar. It is characterized by leisure activities, fishing and agriculture. It receives in its waters expressive raw sewage discharge from a population estimated at more than 250,000 inhabitants. ${ }^{37}$ The mangrove sediment from
Tibiri River used in this work is the same one studied previously by Silva et al. ${ }^{38}$ This sediment was used in this work as blank matrix (Figure 1).

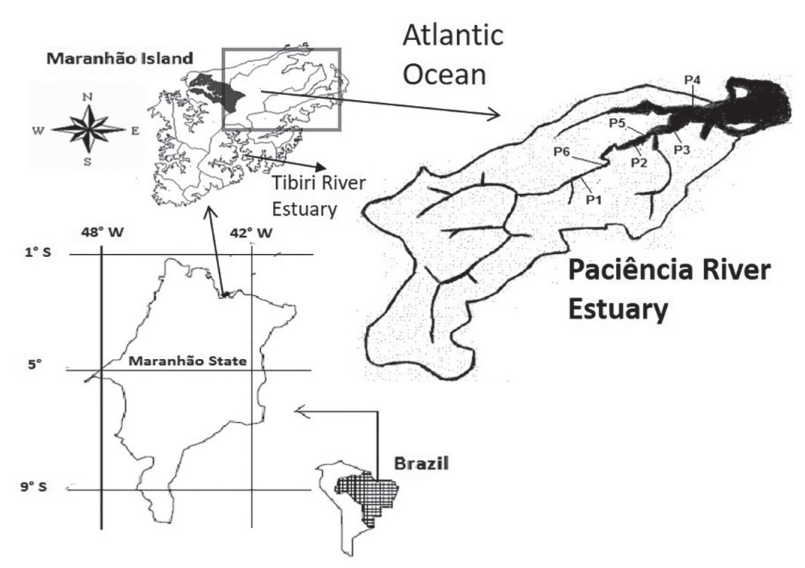

Figure 1. Maranhão Island and rivers Paciência and Tibiri. P1 to P6 represent places along the Paciência River where mangrove sediment samples were collected.

Mangrove sediment samples were collected from Paciência River during one field campaign carried out in August 2014 at six points (P1 [ $2^{\circ} 29^{\prime} 07.10^{\prime \prime} \mathrm{S}$; 44 08' 100.70" O], P2 [2॰ 28' 32.02" S; 44 07 ' 33.54" O],

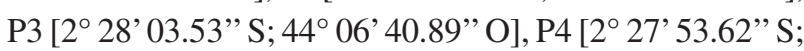

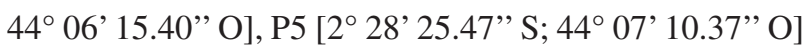
and P6 [2 $2^{\circ} 29^{\prime} 00.33^{\prime \prime} \mathrm{S} ; 4^{\circ} 07^{\prime} 57.25^{\prime}$ ' O]) along the Paciência River during low tide development, spaced approximately $200 \mathrm{~m}$ between sampling. The collection was performed using a stainless steel Van Veen dredge type sampler, specific for sediments. The sediment samples were collected from the surface. Once collected, the samples were packed in polyethylene bags, identified and transported under cooling to the laboratory. In the laboratory, the samples were frozen at $-18^{\circ} \mathrm{C}$, freeze-dried, sieved (sieve $0.63 \mu \mathrm{m}$ ) and stored in amber bottles at $-18{ }^{\circ} \mathrm{C}$ until the time of analysis. ${ }^{26}$ The properties of mangrove sediments for the six sampling points were analyzed using the previously described methods and the resulting average values are: $\mathrm{pH}=6.92 \pm 0.43$; redox potential $\left(\mathrm{E}_{\mathrm{h}}\right)=-126.50 \pm 16.68 \mathrm{mV}$; exchange cation capacity $($ CTC $)=20.90 \pm 2.31\left(\mathrm{cmol} \mathrm{kg}^{-1}\right)$; organic matter $(\mathrm{MO})=12.92 \pm 1.02 \%$, silt + clay $=99 \% .{ }^{38}$

\section{Optimization of extraction conditions}

\section{Ultrasound-assisted extraction (UAE)}

Different experimental conditions in the literature were adapted and tested in order to optimize the simultaneous extraction of the three antibiotics (CIP, LEV and NOR) from the mangrove sediment, as shown in Table 2. 
Table 2. Protocols for extraction using ultrasound-assisted extraction (UAE) of fluoroquinolones antibiotics from sediment

\begin{tabular}{llc}
\hline Method $^{\mathrm{a}}$ & Extraction solution & Reference \\
\hline 1 & $\begin{array}{l}\text { 0.2 M phosphate buffer solution }(\mathrm{pH} 3.0) \\
\text { and methanol 50:50 (v/v) }\end{array}$ & 26 \\
2 & $\begin{array}{l}\text { 0.2 M citrate buffer solution }(\mathrm{pH} 4.0) \text { and } \\
\text { acetonitrile 50:50 (v/v) }\end{array}$ & 34 \\
3 & $\begin{array}{l}\text { aqueous solution of } \mathrm{Mg}\left(\mathrm{NO}_{3}\right)_{2} \text { to 29\% } \\
(\mathrm{m} / \mathrm{v})(\mathrm{pH} 8.1) \text { adjusted with ammonia }\end{array}$ & 35 \\
& $4 \%(\mathrm{v} / \mathrm{v})$ & \\
\hline
\end{tabular}

${ }^{a}$ Volume extraction (10 mL), extraction cycles (3) and extraction time (15 min) are the same for all methods.

For each method, sediment samples ( $1 \mathrm{~g}$ each) were weighed in triplicate in Falcon tubes, and spiked with $200 \mu \mathrm{L}$ of the mixture of three individual standard solutions (CIP, LEV and NOR), each one of them at $1.0 \mathrm{mg} \mathrm{L}^{-1}$ and then kept in the dark at $4{ }^{\circ} \mathrm{C}$ overnight for complete solvent evaporation. After following the steps outlined in Table 2 for each method, the extracts of the samples were centrifuged at $3000 \mathrm{rpm}$ at $25{ }^{\circ} \mathrm{C}$ and the supernatants obtained combined and transferred to amber bottle before making the SPE purification step.

\section{Solid phase extraction}

Extracts of the sediment samples were cleaned and enriched using Oasis HLB cartridges $(60 \mathrm{mg}, 3 \mathrm{~mL}$, Waters, USA). The following protocol was the same for all extraction methods: prior to SFE, the combined extracts were diluted to $100 \mathrm{~mL}$ with Milli-Q water. The Oasis HLB cartridges were preconditioned with $5 \mathrm{~mL}$ of dichloromethane, $5 \mathrm{~mL}$ of methanol and $10 \mathrm{~mL}$ of Milli-Q water adjusted to $\mathrm{pH} 3$ with $\mathrm{H}_{3} \mathrm{PO}_{4}$, successively. Afterward, the aqueous extracts of sediments were performed at a flow rate of $1 \mathrm{~mL} \mathrm{~min}^{-1}$. After all extracts were completely percolated each cartridge was washed with $10 \mathrm{~mL}$ of Milli-Q water solution with $\mathrm{H}_{3} \mathrm{PO}_{4}$ adjusted to $\mathrm{pH} 3$ with $5 \%$ methanol (v/v) to remove impurities weakly bound to the sorbent. Before elution, the cartridges were dried for 30 minutes under a vacuum. The elution of the antibiotic from the cartridges was performed with $6 \mathrm{~mL}$ of $2 \%$ methanolic solution of formic acid (v/v). The eluate containing the target compounds were evaporated to dryness under gentle argon stream, and redissolved with $1 \mathrm{~mL}$ mobile phase followed by filtration through $0.22 \mu \mathrm{m}$ nylon membrane (Chrom Tech, Minnesota, USA) to remove particles prior analysis by HPLC-FD.

\section{Method validation}

In order to assess the selectivity, linearity, accuracy, precision, limit of detection and limit of quantification, sediment samples from the Tibiri River were selected. These sediment samples are similar to Paciência River, but the presence of CIP, LEV and NOR compounds was not identified. The samples were collected in November 2011 in the sediment surface in the estuary of the Tibiri River, located in Maranhão Island, Brazil (Figure 1). The sediment $(\mathrm{pH}=7.9$; organic matter: $16.3 \%$; silt + clay: $99 \%)$ was characterized in a previous study. ${ }^{38}$

\section{Results and Discussion}

\section{Optimization of the extraction procedure}

The extraction of the fluoroquinolones from solid environmental samples requires the application of exhaustive extraction conditions to isolate the analyte of interest, since these compounds bind firmly to this matrix. ${ }^{10,14,34}$ Therefore, it was decided to optimize an extraction technique assisted by ultrasound (UAE) to isolate the CIP, LEV and NOR fluoroquinolones from the mangrove sediment samples. This procedure is easy-to-use (sonication followed by centrifugation), the equipments are easily found in the laboratory, low-cost and uses little solvent extractor..$^{35,39-41}$

Since the fluoroquinolones compounds have amphoteric properties due to the presence of two ionizable functional groups with environmental relevance in its structure, the carboxylic group $\left(\mathrm{pK}_{\mathrm{a}}\right.$ ca. 6) and the amino group $\left(\mathrm{pK}_{\mathrm{a}}\right.$ ca. 8), different mixtures of extracting solutions in acid and basic $\mathrm{pH}$ were evaluated to find an appropriate solution for the extraction of the three antibiotics in sediment samples. The results of these experiments are summarized in Figure 2.23,42



Figure 2. CIP, LEV and NOR recovery values of the three extraction methods applied to the Tibiri River sediment $(n=5)$.

In the most studies involving the extraction of fluoroquinolone antibiotics in solid environmental matrices the extraction of these compounds improves when 
performed at $\mathrm{pH}$ acids. ${ }^{12,26,29,33,34,43}$ In the present study, it can be concluded that, in general, fluoroquinolones were best extracted from the sediment by use of basic solution (method 3) ${ }^{35}$ Importantly, there is no consensus in the literature about the best $\mathrm{pH}$ for the extraction of sediment samples of antibiotics. This shows that the matrix effects are very important in the choice of extraction method. Hence, this method has merit in proposing a way to deal with a complex matrix such as mangrove sediment.

In basic conditions used in method 3 ( $\mathrm{pH} \mathrm{8.1),}$ the LEV has more anionic than zwitterion specie concentration, $\mathrm{pH}=6.77$ (Table 1). For CIP $(\mathrm{pH}=7.5)$ and NOR ( $\mathrm{pH}=7.34$ ) compounds the zwitterions specie is predominant. The cationic species (amino group protonation) are absent for all fluoroquiolones.

The extraction of fluoroquinolones from sediment can be separated into two aspects: (i) octanol-water partition coefficient $\left(\mathrm{K}_{\mathrm{ow}}\right)$ and $(\mathrm{ii})$ distribution coefficient $\left(\mathrm{K}_{\mathrm{d}}\right)$ (Table 1). First, since the fluoroquinolones have relatively low $\mathrm{K}_{\mathrm{ow}}$, due to the presence of many ionizable functional groups, they are preferably solubilized in polar solvents. This could explain the fact observed in extraction process number 3 , which uses only aqueous solution..$^{14,23,42}$ Second, since $\mathrm{K}_{\mathrm{ow}}$ is low, weak sorption would be expected in sediment and soil, but it does not occur. Studies have shown that once present in the sediment, the antibiotics (CIP, LEV and NOR) have low vertical mobility because of their high potential for adsorption. Fluoroquinolones compounds have $\mathrm{K}_{\mathrm{d}}$ ranging from 794 to $\left.19,952\left(\mathrm{~L} \mathrm{~kg}^{-1}\right)\right)^{14,18,44}$ This wide range of $K_{d}$ values reflects that sorption mechanisms are diverse and vary according to the sediment properties, for example, the presence of mineral and organic matter. ${ }^{45,46}$

Minerals play a key role in the adsorption of fluoroquinolones in soil and sediments. Clay mineral and $\mathrm{Al}$ and $\mathrm{Fe}$ oxides are important components in the soil and sediments. Different adsorption mechanisms such as cation exchange (cation exchange capacity), hydrogen bond and complexation (metal oxide content), are involved in adsorption of fluoroquinolones onto soil and sediments. Liu et al. ${ }^{47}$ observed that in modified clay mineral the LEV showed better adsorption in zwitterion with $\mathrm{pH}$ ca. 7 , decreasing for $\mathrm{pH}$ lower or higher than 7. In another work, Yang et al. ${ }^{26}$ concluded that ciprofloxacin showed better adsorption on clay mineral (montmorillonite, rectorite, and illite) in acid $\mathrm{pH}$. In this condition, the cationic species of ciprofloxacin is adsorbed by cation exchange mechanism. In this way, Vasudevan et al., ${ }^{15}$ by investigating different types of soils, also concluded that the cationic specie of ciprofloxacin was the most important specie in sorption mechanism in acid $\mathrm{pH}$ and the sorption rates varied in function of soil type. In addition, the authors suggested that organic matter is not fundamental for ciprofloxacin sorption regarding hydrophobic properties $\left(\mathrm{K}_{\mathrm{ow}}\right)$. The $\mathrm{K}_{\mathrm{oc}}$ (partition coefficient between organic carbon and water) seems unsuitable to express sorption capacity in soil and sediment. ${ }^{14}$ Also in acid pH, according to Leal et al. ${ }^{48}$ by investigating Brazilian soils, fluoroquinolones demonstrated very high sorption $\left(\mathrm{K}_{\mathrm{d}} \geq 544 \mathrm{~L} \mathrm{~kg}^{-1}\right)$. Based on what was mentioned above, three explanations for the method 3 performance were hypothesized: (i) the anionic specie can suffer repulsion of the negative sites in the surface of the sediment particles formed by clay minerals and iron oxides among others; (ii) in association with the previous mechanism, antibiotic/ $\mathrm{Mg}^{2+}$ complex contributes to increasing the fluoroquinolones solubility; $10,35,49,50$ and (iii) on the other hand, the acid $\mathrm{pH}$ of methods 1 and 2 favors the cation exchange sorption mechanism, since the mangrove sediment has high exchange cation capacity $\left(\mathrm{CTC}=20.90 \mathrm{cmol} \mathrm{kg}^{-1}\right)$.

\section{Analytical performance}

In order to ensure the reliability of analytical results, some figures of merit were determined to guarantee the successful use of the proposed methodology, in addition to finding errors of the analytical protocols.

\section{Selectivity}

The selectivity of the method was evaluated by comparing the chromatograms obtained from the extract of Tibiri River sediment without and with fluoroquinolones fortification to verify the presence of some interfering matrix in the same analyte retention times.

By overlaying the chromatograms it was observed that there were no interferences (Figure 3). The presence of co-extractives from the matrix did not elute at the same retention times of the analytes under current study. This fact is of great importance because the mangrove sediments are rich in organic matter due to the high biological productivity. This organic matter undergoes microbial degradation, generating numerous organic and inorganic compounds. For example, in the study of sediment samples from the Pearl River in China, the authors could not determine some antibiotics (CIP and NOR) due to serious interference of compounds present in the extracts evaluated. ${ }^{26}$

\section{Linearity}

For the study of linearity method, it was prepared an external calibration curve using six concentration levels set in triplicates $\left(20,25,50,100,200\right.$ and $500 \mu \mathrm{g} \mathrm{L}{ }^{-1}$, prepared in ultrapure water). Each calibration curve was constructed according to the relationship between the analytical signal presented and the concentration of the substance of interest. 


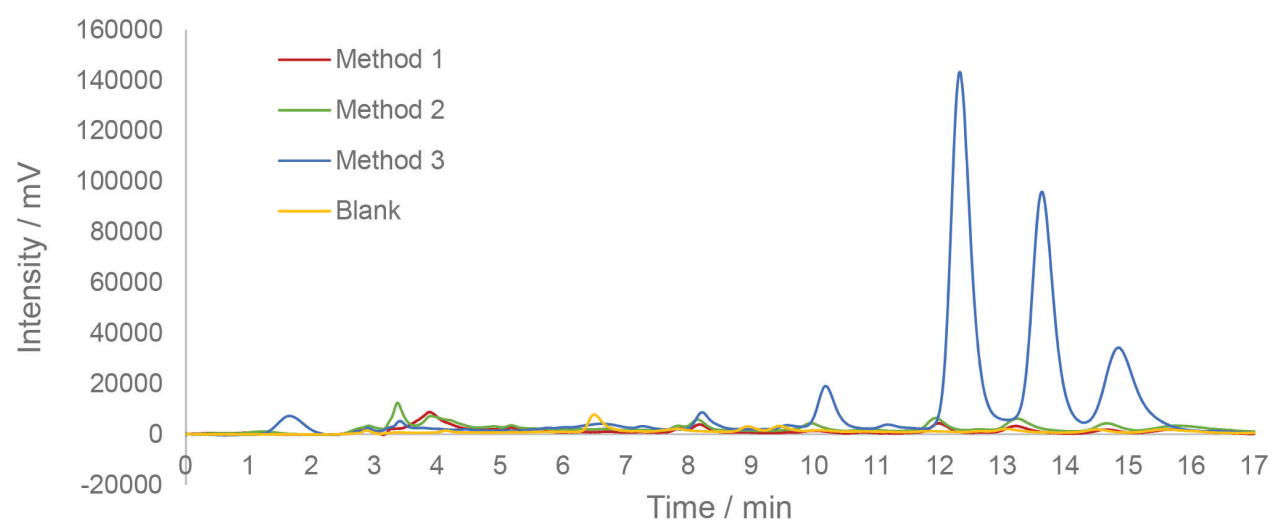

Figure 3. HPLC-FD chromatograms obtained from extraction methods: blank matrix using method 3 (yellow) and fortified matrices with CIP, LEV and NOR at $200 \mu \mathrm{g} \mathrm{kg}^{-1}$ using methods 1 (red), 2 (green) and 3 (blue), respectively.

The values were used to obtain the linear regression equation by the least square method. The linear correlation coefficient $\left(\mathrm{r}^{2}\right)$ was used to verify the adequacy of the representation of the mathematical model expressed by the linear equation. An $\mathrm{r}^{2}$ value greater than 0.995 was required to consider the satisfactory linear model..$^{51-54}$

The analytical curves for the three fluoroquinolones (Table 3) were shown to be linear over the studied range, with satisfactory $\mathrm{r}^{2}$ since they achieved values greater than 0.995 for CIP, LEV and NOR, i.e., very strong correlation. $^{52,55,56}$

Table 3. Quantitative parameters for typical analytical curves obtained by HPLC-FD for compounds LEV, NOR and CIP

\begin{tabular}{lccc}
\hline Analyte & $\begin{array}{c}\text { Retention } \\
\text { time } / \mathrm{min}\end{array}$ & Linear equation & $\mathrm{r}^{2}$ \\
\hline LEV & 10.4 & $\mathrm{y}=0.451 \mathrm{x}+0.443$ & 0.9997 \\
NOR & 12.3 & $\mathrm{y}=3.163 \mathrm{x}-4.771$ & 0.9999 \\
CIP & 13.6 & $\mathrm{y}=2.655 \mathrm{x}-2.198$ & 0.9999 \\
\hline
\end{tabular}

$\mathrm{r}^{2}$ : correlation coefficient.

Limits of detection and quantification

The limits of detection (LOD) and quantification (LOQ) were established from the blank matrix (Tibiri River sediment). The standard deviation was obtained by injecting at least ten times the sample blank for subsequent application of formula LOD $(3 \mathrm{~s} / \mathrm{S})$ and LOQ $(10 \mathrm{~s} / \mathrm{S})$, where $\mathrm{s}$ is the standard deviation of the background and $\mathrm{S}$ is the slope of the analytical curve. ${ }^{51-53}$

LOD and LOQ were considered satisfactory (Table 4), mainly for the purpose of the method, which evaluates antibiotic residues in complex matrices such as mangrove sediment. The present method is in the range of detection limits found in the literature. For example, Li et al. ${ }^{57}$ by using liquid chromatography with mass detector (LC-MS/MS), obtained an LOD ranging from 0.08 to $2.86 \mu \mathrm{g} \mathrm{kg}^{-1}$.
Table 4. LOD and LOQ values for the three fluoroquinolones

\begin{tabular}{lcc}
\hline Analyte & $\mathrm{LOD} /\left(\mu \mathrm{g} \mathrm{kg}^{-1}\right)$ & $\mathrm{LOQ} /\left(\mu \mathrm{g} \mathrm{kg}^{-1}\right)$ \\
\hline CIP & 1.10 & 3.68 \\
LEV & 3.33 & 11.10 \\
NOR & 0.26 & 0.86 \\
\hline
\end{tabular}

LOD: limit of detection; LOQ: limit of quantification.

\section{Recovery and matrix effect}

Accuracy was assessed from recovery tests using the extraction method proposed in this study for the three fluoroquinolones. To assess the recovery, sediment samples from Tibiri River were spiked with a mixture of three individual standard solutions (CIP, LEV and NOR) in three fortification levels: 20, 200 and $500 \mu \mathrm{g} \mathrm{kg}{ }^{-1}$. At least five analyses were performed for each of the three fortification levels studied. The recovery percentage was calculated from the ratio between the average concentration determined experimentally and the corresponding theoretical concentration. The average percentage recoveries of the analytes are given in Table 5.

Table 5. Antibiotics recovery in mangrove sediments and relative standard deviation of the compounds

\begin{tabular}{lccc}
\hline Analyte & $\begin{array}{c}\text { Spiked level/ } \\
\left(\mu \mathrm{g} \mathrm{kg}^{-1}\right)\end{array}$ & Recovery / \% & RSD / \% \\
\hline \multirow{3}{*}{ CIP } & 20 & 76.67 & 8.79 \\
& 200 & 73.73 & 4.26 \\
\hline \multirow{4}{*}{ LEV } & 500 & 76.43 & 3.60 \\
\hline & 20 & 85.73 & 2.51 \\
& 200 & 88.85 & 3.96 \\
NOR & 500 & 87.64 & 6.57 \\
& 20 & 81.52 & 4.71 \\
& 200 & 82.85 & 2.62 \\
\hline
\end{tabular}

RSD: relative standard deviation for 5 replicates. 
The method was considered to be accurate since it included recoveries in the range between 70 and $120 \%$ established in the literature for residue analysis and their values repeated in all samples indicating the consistency of the method. ${ }^{51-53}$

The presence of matrix effect in a complex sample such as the mangrove sediment is not uncommon. In order to evaluate the matrix effect on signal intensity, this work used the equation described by Vieno et al..$^{58}$ The following set of solutions was prepared: (i) standard solution of CIP, LEV and NOR at $200 \mu \mathrm{g} \mathrm{kg}^{-1}$; (ii) un-spiked sediment extracts and (iii) spiked sediment extracts with CIP, LEV and NOR at $200 \mu \mathrm{g} \mathrm{kg}^{-1}$. According to the equation, the matrix effects values obtained were CIP (0.27), LEV (0.14) and NOR (0.18). Although undesirable, these values do not represent a limiting aspect for method validation.

\section{Precision}

Precision was determined by repeatability levels from the analysis of three concentration levels (20, 200 and $500 \mu \mathrm{g} \mathrm{kg}^{-1}$ ) with at least five tests each on the same day and same experimental conditions. The results were expressed by estimating the relative standard deviation (RSD) shown in Table 5 and were considered adequate, as they are within the recommended limits for residue analysis $(\leq 20 \%)$, indicating that the developed method is precise within the concentration range and the adopted conditions. ${ }^{52}$

\section{Analysis of environmental sediment samples}

The sediment is an environmental compartment that has a great ability to accumulate different types of pollutants, including pharmaceuticals, which makes it a true witness to the environmental impacts suffered by aquatic ecosystems over time. ${ }^{59}$ The concentrations of the antibiotics in the sediment samples collected in the Paciência River are shown in Table 6.

Among the antibiotics investigated in this study, only CIP was detected in three of the six sites evaluated. One
Table 6. Concentrations of the compounds investigated in the Paciência River sediments

\begin{tabular}{lccc}
\hline Site & $\begin{array}{c}\mathrm{CIP} \pm \mathrm{SD} / \\
\left(\mu \mathrm{kg}^{-1}\right)\end{array}$ & $\begin{array}{c}\mathrm{LEV} \pm \mathrm{SD} / \\
\left(\mu \mathrm{gg}^{-1}\right)\end{array}$ & $\begin{array}{c}\mathrm{NOR} \pm \mathrm{SD} / \\
\left(\mu \mathrm{g} \mathrm{kg}^{-1}\right)\end{array}$ \\
\hline 1 & $60.08 \pm 5.56$ & n.d & n.d \\
2 & n.d & n.d & n.d \\
3 & $70.45 \pm 4.81$ & n.d & n.d \\
4 & n.d & n.d & n.d \\
5 & $56.55 \pm 4.45$ & n.d & n.d \\
6 & n.d & n.d & n.d \\
\hline
\end{tabular}

SD: standard deviation; n.d: not detected.

possible explanation to CIP contamination derives from the fact that the Paciência River basin undergoes a great domestic sewage discharge of the untreated effluents from urban activities spread in this basin (São Luís, Raposa, Paço do Lumiar and São José de Ribamar cities). ${ }^{37}$

Literature data related to sediment contamination by fluoroquinolones report the same route of entry, and similar contamination levels or even higher. ${ }^{26,28,36,60}$ Table 7 shows a comparison among the concentrations of fluoroquinolones found in other sediments around the world.

The results presented in Table 7 are the first dates about fluoroquinolones in mangrove sediment in Maranhão Island. The relevance becomes greater due to the almost non-existent treatment of sewage in this area. The mangrove is an ecosystem that occur in large areas of Brazil and around the planet. Therefore, the present study offers a relevant alternative for antibiotics investigation in sediment, since the literature on this problem is scarce.

\section{Conclusions}

The methodology based on aqueous ultrasound assisted extraction (UAE) and solid phase extraction (SPE) followed by the HPLC-FD was optimized for the analysis of the fluoroquinolones antibiotics in mangrove sediment.

Table 7. Fluoroquinolone concentrations found in other regions

\begin{tabular}{lccc}
\hline Region & Fluoroquinolone & Concentration & Reference \\
\hline Rio Pearl, China & CIP & $9.02-197 \mu \mathrm{g} \mathrm{kg}^{-1}$ & 26 \\
Valência, Spain & NOR & $19.2-1120 \mathrm{~g} \mathrm{~kg}^{-1}$ & 28 \\
Yellow, Hai and Liao Rivers, China & CIP & $5.95 \mathrm{ng} \mathrm{g}^{-1}$ & 36 \\
Baiyangdian Lake, China & CIP & $32.8 ; 1290 ; 28.7 \mathrm{ng} \mathrm{g}^{-1}$ & 60 \\
& NOR & $141 ; 5770 ; 176 \mathrm{ng} \mathrm{g}^{-1}$ & $2.49 \mu \mathrm{gg} \mathrm{g}^{-1}$ \\
Paciência River, São Luís-MA, Brazil & CIP & $267 \mu \mathrm{g} \mathrm{kg}^{-1}$ & this study \\
\hline
\end{tabular}


The UAE-SPE-HPLC-FD methodology provides a low detection limit $\left(1.10,3.33\right.$ and $0.26 \mu \mathrm{g} \mathrm{kg}^{-1}$ to CIP, LEV and NOR, respectively) and high linear coefficient $\left(\mathrm{r}^{2}>0.999\right)$. Additionally, in real mangrove sediment samples, the recovery (\%) ranged from 73.73 to $88.85 \%$, proving that the complexity of the matrix does not interfere significantly in the extraction efficiency. UAE-SPE-HPLC-FD is relatively simple, precise and accurate. Also, the methodology has expressive clean up capacity.

The method was applied in the determination of pharmaceuticals in mangrove sediment of the Paciência River, Maranhão Island, Brazil, where only the CIP antibiotic was found in three of six samples analyzed, with values ranging from $56.55-70.45 \mu \mathrm{g} \mathrm{kg}^{-1}$.

\section{Acknowledgments}

This work was supported by the National Council of Technological and Scientific Development (CNPq) and the Foundation of Research and Scientific and Technological Development of Maranhão (FAPEMA). The authors thank the Chemistry Department of the Federal Institute of Education Science and Technology of Maranhão (Monte Castelo Campus, IFMA) and Federal University of Maranhão (UFMA).

\section{References}

1. Guimarães, D. O.; Momesso, L. S.; Pupo, M. T.; Quim. Nova 2010, 33, 667.

2. Santos, P. N.; Maciel, M. I. S.; Lavorante, B. R. B. O.; Medeiros, M. M.; Albuquerque Júnior, E. C.; Quim. Nova 2011, 34, 1265.

3. Kemper, N.; Ecol. Indic. 2008, 8, 1 .

4. Sapkota, A.; Sapkota, A. R.; Kucharski, M.; Burke, J.; McKenzie, S.; Walker, P.; Lawrence, R.; Environ. Int. 2008, $34,1215$.

5. Kümmerer, K.; Annu. Rev. Environ. Resour. 2010, 35, 57.

6. Morris, D.; Harris, S.; Morris, C.; Commins, E.; Cormican, M.; Hospital Effluent: Impact on the Microbial Environment and Risk to Human Health; Research Report No. 162 (2008-EHMS-6-S3); EPA: Wexford, Ireland, 2016.

7. Bila, D. M.; Dezotti, M.; Quim. Nova 2003, 26, 523.

8. Silva, C. G. A.; Collins, C. H.; Quim. Nova 2011, 34, 665.

9. https://amr-review.org/sites/default/files/Antimicrobials $\% 20$ in $\% 20$ agriculture $\% 20$ and $\% 20$ the $\% 20$ environment $\% 20-\% 20$ Reducing\%20unnecessary $\% 20$ use $\% 20$ and $\% 20$ waste.pdf, accessed on April 22, 2017.

10. Leal, R. M.; Figueira, R. F.; Tornisielo, V. L.; Regitano, J. B.; Sci. Total Environ. 2012, 432, 344.

11. Tadeo, J. L.; Sánchez-Brunete, C.; Albero, B.; García-Valcárcel, A. I.; Pérez, R. A.; Cent. Eur. J. Chem. 2012, 10, 480.
12. Dorival-García, N.; Zafra-Gómez, A.; Camino-Sánchez, F. J.; Navalón, A.; Vílchez, J. L.; Talanta 2013, 106, 104.

13. Salvia, M. V.; Fieu, M.; Vulliet, E.; Appl. Environ. Soil Sci. $\mathbf{2 0 1 5}, 2015,1$.

14. Tolls, J.; Environ. Sci. Technol. 2001, 35, 3397.

15. Vasudevan, D.; Bruland, G. L.; Torrance, B. S.; Upchurch, V. G.; MacKay, A.; Geoderma 2009, 151, 68.

16. Van Doorslaer, X.; Dewulf, J.; Van Langenhove, H.; Demeestere, K.; Sci. Total Environ. 2014, 500-501, 250.

17. Ahmad, I.; Bano, R.; Sheraz, M. A.; Ahmed, S.; Mirza, T.; Ansari, S. A.; Acta Pharm. 2013, 63, 223.

18. Sarisaltik, D.; Teksin, Z. F.; FABAD J. Pharm. Sci. 2007, 32, 197.

19. Uivarosi, V.; Molecules 2013, 18, 11153.

20. da Silva, J. M. B.; Hollenbach, C. B.; Arq. Inst. Biol. 2010, 77, 363.

21. http://www.moreirajr.com.br/revistas.asp?fase=r003\&id_ materia=2632, accessed on April 22, 2017.

22. Speltini, A.; Sturini, M.; Maraschi, F.; Profumo, A.; Albini, A.; Trends Anal. Chem. 2011, 30, 1337.

23. Picó, Y.; Andreu, V.; Anal. Bioanal. Chem. 2007, 387, 1287.

24. Li, Y.; Li, Q.; Zhou, K.; Sun, X.; Zhao, L.; Zhang, Y.; Chemosphere 2016, 147, 25.

25. Seifrtová, M.; Pena, A.; Lino, C. M.; Solich, P.; Anal. Bioanal. Chem. 2008, 391, 799.

26. Yang, J. F.; Ying, G. G.; Zhao, J. L.; Tao, R.; Su, H. C.; Chen, F.; Sci. Total Environ. 2010, 408, 3424.

27. Runnqvist, H.; Bak, S. A.; Hansen, M.; Styrishave, B.; HallingSørensen, B.; Björklund, E.; J. Chromatogr. A 2010, 1217, 2447.

28. Vazquez-Roig, P.; Segarra, R.; Blasco, C.; Andreu, V.; Picó, Y.; J. Chromatogr. A 2010, 1217, 2471.

29. Golet, E. M.; Strehler, A.; Alder, A. C.; Giger, W.; Anal. Chem. 2002, 74, 5455.

30. Christian, T.; Schneider, R. J.; Färber, H. A.; Skutlarek, D.; Meyer, M. T.; Goldbach, H. E.; Acta Hydrochim. Hydrobiol. 2003, 31, 36.

31. Sturini, M.; Speltini, A.; Maraschi, F.; Rivagli, E.; Profumo, A.; J. Chromatogr. A 2010, 1217, 7316.

32. Hu, X.; Zhou, Q.; Chromatographia 2011, 74, 489.

33. Martínez-Carballo, E.; González-Barreiro, C.; Scharf, S.; Gans, O.; Environ. Pollut. 2007, 148, 570.

34. Uslu, M. Ö.; Yediler, A.; Balcıŏlu, I. A.; Schulte-Hostede, S.; Water, Air, Soil Pollut. 2008, 1901, 55.

35. Turiel, E.; Martín-Esteban, A.; Tadeo, J. L.; Anal. Chim. Acta 2006, 562, 30.

36. Zhou, L. J.; Ying, G. G.; Zhao, J. L.; Yang, J. F.; Wang, L.; Yang, B.; Liu, S.; Environ. Pollut. 2011, 159, 1877.

37. http://imesc.ma.gov.br/src/upload/publicacoes/579d2d548033 4a4bafbd95d68fcaceaf.pdf, accessed in January 2016. 
38. Silva, G. S.; Nascimento, A. S.; Sousa, E. R.; Marques, E. P.; Marques, A. L. B.; Corrêa, L. B.; Silva, G. S.; Rev. Virtual Quim. 2014, 6, 323.

39. Blackwell, P. A.; Holten Lützhøft, H. C.; Ma, H. P.; HallingSørensen, B.; Boxall, A. B.; Kay, P.; Talanta 2004, 64, 1058.

40. Tadeo, J. L.; Sánchez-Brunete, C.; Albero, B.; García-Valcárcel, A. I.; J. Chromatogr. A 2010, 1217, 2415.

41. Carvalho, P. N.; Pirra, A.; Basto, M. C. P.; Almeida, C. M. R.; Anal. Methods 2013, 5, 6503.

42. Leyva, S.; Leyva, E.; Bol. Soc. Quím. Mex. 2008, $2,1$.

43. Kim, S. C.; Carlson, K.; Anal. Bioanal. Chem. 2007, 387, 1301.

44. Kümmerer, K.; Chemosphere 2009, 75, 417.

45. Thiele-Bruhn, S.; J. Plant Nutr. Soil Sci. 2003, 166, 145.

46. Pereira, L. A.; Jardim, I. C. S. F.; Fostier, A. H.; Rath, S.; Quim. Nova 2012, 35, 159.

47. Liu, X.; Liu, Y.; Xu, J. R.; Ren, K. J.; Meng, X. Z.; Environ. Pollut. 2016, 219, 916.

48. Leal, R. M. P.; Alleoni, L. R. F.; Tornisielo, V. L.; Regitano, J. B.; Chemosphere 2013, 92, 979.

49. Park, H. R.; Chung, K. Y.; Lee, H. C.; Lee, J. K.; Bark, K. M.; Bull. Korean Chem. Soc. 2000, 21, 849.

50. Park, H. R.; Kim, T. H.; Bark, K. M.; Eur. J. Med. Chem. 2002, $37,443$.
51. Amarante Júnior, O. P.; Caldas, E. P. A.; Brito, N. M.; Santos, T. C. R.; Vale, M. L. B. F.; Cad. Pesqui. 2001, 12, 116.

52. Brito, N. M.; Amarante Júnior, O. P.; Polese, L.; Ribeiro, M. L.; Pesticidas: R. Ecotox. Meio Ambiente 2003, 13, 129.

53. Ribani, M.; Bottoli, C. B. G.; Collins, C. H.; Jardim, I. C. S. F.; Melo, L. F. C.; Quim. Nova 2004, 27, 771.

54. Lanças, F. M.; Cromatografia Liquida Moderna (HPLC/CLAE), $1^{\text {a }}$ ed.; Átomo: São Paulo, Brazil, 2009.

55. http://redsang.ial.sp.gov.br/site/docs_leis/vm/vm1.pdf, accessed in December 2015.

56. http://www.inmetro.gov.br/Sidoq/Arquivos/Cgcre/DOQ/DOQCgcre-8_04.pdf, accessed in June 2017.

57. Li, Y.; Li, Q.; Zhou, K.; Sun, X. L.; Zhao, L. R.; Zhang, Y. B.; Chemosphere 2016, 147, 25.

58. Vieno, N. M.; Tuhkanen, T.; Kronberg, L.; J. Chromatogr. A 2006, 1134, 101.

59. Pereira, J. C.; Guimarães-Silva, A. K.; Nalini Júnior, H. A.; Pacheco-Silva, E.; Lena, J. C.; Quim. Nova 2007, 30, 1249.

60. Wenhui, L.; Yali, S.; Lihong, G.; Jiemin, L.; Yaqi, C.; Chemosphere 2012, 89, 1307.

Submitted: February 23, 2017

Published online: June 13, 2017 